\title{
REAL ESTATE'S KNOWLEDGE AND DEVICE-BASED DECISION SUPPORT SYSTEM
}

\author{
Edmundas Kazimieras ZAVADSKAS ${ }^{1}$, Artūras KAKLAUSKAS ${ }^{2} \bowtie$ \\ and Audrius BANAITIS ${ }^{3}$ \\ ${ }^{1}$ Department of Construction Technology and Management, Vilnius Gediminas Technical \\ University, Sauletekio al. 11, LT-10223 Vilnius, Lithuania \\ E-mail:edmundas.zavadskas@vgtu.lt \\ ${ }^{2}$ Department of Construction Economics and Property Management, Vilnius Gediminas \\ Technical University, Sauletekio al. 11, LT-10223 Vilnius, Lithuania \\ E-mail: arturas.kaklauskas@vgtu.lt \\ ${ }^{3}$ Department of Construction Economics and Property Management, Vilnius Gediminas \\ Technical University, Sauletekio al. 11, LT-10223 Vilnius, Lithuania \\ E-mail: audrius.banaitis@vgtu.lt
}

Received 2 September 2009; accepted 10 December 2009

\begin{abstract}
The authors of this paper participated in the European Union's Sixth Framework Programme project Intelligent Cities (INTELCITIES, 2005). One of INTELCITIES's goals (on the Lithuanian side) was to develop a Real Estate's Knowledge and Device-based Decision Support System (KDDSS-RE). Major KDDSS-RE functions include creating and maintaining customer's personalized real estate objectives, preferences, and evaluation criteria; participation of various stakeholders (buyers, sellers, brokers, etc.) in joint determination of criteria (criteria system, values and weights) defining real estate; market signalling, provide device-based data about indoor microclimates and allergens causing allergy in buildings; searching for real estate alternatives, finding alternatives and making an initial negotiation table, completing a multiple criteria analysis of alternatives, making electronic negotiations based on real calculations, determining the most rational real estate purchase variant, and completing an analysis of loan alternatives offered by certain banks. The authors of the present research have suggested the idea to integrate knowledge-based, devices-based and decision support systems. In order to demonstrate the integration decision support, knowledge and devices systems in the real estate sector a Real Estate's Knowledge and Devices-based Decision Support System have been considered in the paper as an example.
\end{abstract}

KEYWORDS: Real estate; Decision support system; Multiple criteria analysis

\section{INTRODUCTION}

The e-commerce revolution has begun to transform a host of information-based service industries - including travel services, banking, and securities trading - bringing new efficiencies, reduced costs, and more consumer choices. The real estate industry has lagged behind many other industries in e-transformation and still relies largely on face-to-face transactions, paper-intensive processes, and mediators to negotiate a myriad of complex facets of a typical purchase.

The speedy boost of the Internet and intelligent technologies and applications in recent years has the driven real estate sector 
towards adopting innovative e-transformations. Unavoidably, the real estate sector has also clashed with new challenges that moved them forward to implement innovative Internet and intelligent technologies. Developing innovative services is very important for the survival of stakeholders in the real estate sector because of grim market competition and an increase of competitive abilities. The growing demand for information and knowledge-based decision-support facilities that integrate personalized and collaborative needs and requirements in all real estate sector activities has also been noticed lately.

Throughout the world there are many examples of the adoption of Web-based information and intelligent systems in real estate. Some of them are as follows: e-commerce (Muhanna, 2000; Teicholz, 2000), valuation (Zavadskas et al., 2007a; Šliogerienè et al., 2009), brokerage (Guttery et al., 2000; Ham and Atkinson, 2003; Zumpano et al., 2003), facility management and maintenance (ARCHIBUS, Inc., 2009; FM:Systems, 2009; Ko, 2009), mortgages (mortgage.com, 2009; E-Loan, Inc., 2009), real estate management (Drawbase Software, 2009), insurance (BIG, 2009), project development (RealData, Inc., 2009), sustainable development and planning (Onishi, 2002; Curwell et al., 2005; Zavadskas et al., 2007b; Jakaitis et al., 2009; Jauneikaitè and Carreno, 2009; Simão et al., 2009; Stankevičius et al., 2010), evaluation for real estate investment (Wang, 2005; Guo et al., 2007), matching/listing services (Benjamin et al., 2000; Ford et al., 2005), negotiation (Kaklauskas and Urbanavičienè, 2005; Urbanavičienè et al., 2009a, 2009b), real estate's transaction process (Cao et al., 2001; Fang et al., 2009), procurement (Vitkauskaitè and Gatautis, 2008) etc. For example, in Forbes (2000a, 2000b, 2000c) opinion, the corporation of tomorrow must successfully integrate facilities management with finance and administrative activities, sales and marketing, human resources, information management, manufacturing, distribution, and these should be Web centric. Also, Forbes (2000a, 2000b, 2000c) emphasizes, that the use of e-commerce by facilities management professionals is still new, but there is little doubt that its presence will be lasting and more significant in the years to come.

The authors of this paper participated in the European Union's Sixth Framework Programme project Intelligent Cities (INTELCITIES, 2005). One of the INTELCITIES's goals (on the Lithuanian side) was to develop a Real Estate's Knowledge and the Device-based Decision Support System (KDDSS-RE) that can use best practices as well as explicit and tacit knowledge.

This paper is structured as follows: following this introduction, Section 2 describes Real Estate's Knowledge and the Device-based Decision Support System. Testing the developed system is presented in Section 3. Finally, some concluding remarks are provided in Section 4.

\section{REAL ESTATE'S KNOWLEDGE AND DEVICE-BASED DECISION SUPPORT SYSTEM}

Major KDDSS-RE functions include creating and maintaining customer's personalized real estate objectives, preferences, and evaluation criteria; participation of various stakeholders (buyers, sellers, brokers, etc.) in joint determination of criteria (criteria system, values and weights) defining real estate; market signalling, providing device-based data about the indoor microclimate and allergens causing allergy in the building; searching for real estate alternatives, finding alternatives and making an initial negotiation table, completing a multiple criteria analysis of alternatives, making electronic negotiations based on real calculations, determining the most rational real estate purchase variant, and completing an analysis of the loan alternatives offered by certain banks. 
The KDDSS-RE consists of a Decision Support Subsystem, Knowledge Subsystem and Devices Subsystem. A more detailed description of these Subsystems follows.

Decision Support Subsystem (DSS-RE) consists of a database, a database management system, model-base, a model-base management system and a user interface (see Figure 1). The Decision Support Subsystem was developed by using methods (Zavadskas et al., 2004; Kaklauskas et al., 2005; Kaklauskas et al., 2007; Banaitienè et al., 2008; Kaklauskas et al., 2010) that were developed by authors, i.e. a method of complex determination of the weights of the criteria taking into account their quantitative and qualitative characteristics; a method of multiple criteria complex proportional evaluation of the projects; and a method of defining the utility and market value of a real estate.

Real estate listings are an interface for a seller to post listings. The system provides forms for completion by sellers or real estate brokers on information about their real estate. Real estate brokers wishing to present infor- mation on their objects must receive permission from DSS-RE administrator. Having this permission the broker then inserts all the necessary information about real estate objects under sale in the DSS-RE databases according to the system's requirements (i.e. system of criteria, values and weights of criteria). Access to databases developed personally by brokers is provided only to the broker and to the DSS-RE administrator. At present the developed DSS-RE allows for the performance of eight main functions, which are presented in Figure 1. In order to throw more light on the DSS-RE, a more detailed description of some of the above-mentioned Subsystem functions follows.

The Data Search and Navigation Module give a buyer a search and navigational instrument to retrieve and browse exhaustive real estate data and alternatives such as single family house, two, three or four-room flats in different locations and of different quality, etc. Buyers can also choose and keep/save attractive real estate alternatives in a personal preferred list.

\begin{tabular}{|c|c|}
\hline \multicolumn{2}{|r|}{ Decision Support Subsystem (RE-DSS) } \\
\hline & $\downarrow$ \\
\hline \multicolumn{2}{|r|}{ User interface } \\
\hline$\downarrow$ & 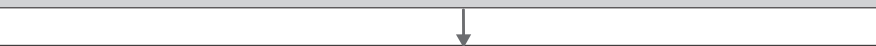 \\
\hline $\begin{array}{c}\text { Database management } \\
\text { system }\end{array}$ & Model base management system (main functions) \\
\hline & 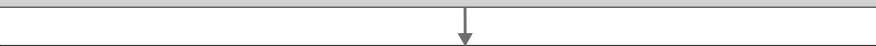 \\
\hline $\begin{array}{l}\text { Databases of dwelling } \\
\text { real estate (apartments } \\
\text { in houses with few } \\
\text { flats, apartments in } \\
\text { blocks of flats, garden } \\
\text { houses, farmsteads, } \\
\text { cottages, private } \\
\text { houses), commercial } \\
\text { real estate (premises, } \\
\text { buildings), rent flats, } \\
\text { loans, etc. }\end{array}$ & $\begin{array}{l}\text { - Searching and navigation model for real estate al ternatives. } \\
\text { - M odel for finding al ternatives and making an initial } \\
\text { negotiation table. } \\
\text { - Collaborative work model. } \\
\text { - M odel of multiple criteria analysis of real estate and other } \\
\text { alternatives. } \\
\text { - M odel for negotiations based on real calculations. } \\
\text { - M odel for determining the most rational real estate purchase } \\
\text { variant. } \\
\text { - M odel of consumer needs analysis and provision of } \\
\text { recommendations to a real estate broker. } \\
\text { - M odel for determining the rational loan. }\end{array}$ \\
\hline
\end{tabular}

Figure 1. Components of Decision Support Subsystem 
This real estate search and navigation module is available in the following databases: databases of dwelling real estate (apartments in houses with few flats, apartments in blocks of flats, garden houses, farmsteads, cottages and private houses), commercial real estate (premises, buildings), rented flats and loans, etc. A consumer may perform a search for real estate alternatives from databases with different brokers. This is possible because the forms of data submissions are standardized at a specific level. Such standardization creates conditions that can be applied to special intelligent agents that are performing a search for the required real estate in various databases, and for the gathering information/knowledge.

Consumers specify requirements and constraints and the system queries the information of a specific real estate from a number of online brokers. The system performs the tedious, time-consuming, and repetitive tasks of searching databases, retrieving and filtering information/knowledge, and delivering it back to the user. Search results for a specific real estate are submitted in a textual, photo/video and graphical information on the real estate's alternatives and the initial negotiation table, which may include direct links to a broker's Web page. When submitting such a display, the multiple criteria comparisons will become more effectively supported.

The brokers or sellers offer many different real estate alternatives to the market, while at the same time buyers identify their detailed requirements. First, buyers are offered a system of typical criteria on the basis of which real estate evaluators and buyers evaluate real estate alternatives. Buyers can offer their own system of criteria based on this system of typical criteria and on their needs. Similarly, initial weights of criteria and values of qualitative indicators are determined. Buyers receive typical weights of criteria and values of qualitative criteria describing the analysed real estate. Buyers can change the offered typical weights of criteria and of qualitative indicators on the basis of their experiences and needs. In such a case, each buyer receives a personalised and specifically adjusted decision-making matrix. One person or a group of stakeholders (e.g. the whole family) can participate in the process of determining the system of criteria, their weights and values of qualitative indicators.

The Collaborative Work Module allows different stakeholders (e.g. family members) in collaborative ways to solve common tasks (development of joint criteria system, estimation of criteria weight and qualitative criteria values). The Groopware Module allows stakeholders to share ideas and to vote and select the one with the highest votes as a jointly accepted real estate alternative.

By using Real Estate and other Alternatives Analysis Module buyers may indicate their tasks and preferences by changing criteria systems, criteria values and weight. A buyer can retrieve previously stored information from a previously developed personalized database or directly insert data through an input screen for a concrete case and activate the multiple criteria analysis process. The results are module recommended real estate, loan, brokers, insurance, leasing, work, facilities management and other alternatives that personally match the buyers' tasks and preferences.

While going through the purchasing decision process a customer should examine a large number of alternatives, each of which is surrounded by a considerable amount of information/knowledge (economic, quality-architectural, aesthetic, comfort, infrastructure, and technical, legal, technological) and other factors. Following on from the gathered information and knowledge, the multiple criteria analysis is then carried out. By using multiple criteria methods (Zavadskas et al., 2004; Kaklauskas et al., 2005; Kaklauskas et al., 2007; Banaitienè et al., 2008; Kaklauskas et al., 2010) as was developed by the authors, the buyer (broker) determines the initial priority, utility degree and market value of the analyzed real estate's alternatives during this analysis. Clicking the 
link 'Results of Multiple Criteria Evaluation', the results of the multiple criteria evaluation of 3-room apartment's alternatives are thus demonstrated (see Figure 2). In the lower part of the obtained result's matrix the calculated significance of the real estate's alternatives their priority and utility degree are presented (see Figure 2 (right)). The upper part of the obtained result's matrix shows the numbering of real estate's alternatives (see Figure 2 $(l e f t)$ ). By clicking the underlined numbers it is possible to calculate the market value of a certain alternative (see Figure 3). The table presented in Figure 3 shows the iterations made during the calculation of the real estate's market value. The same information, only in graphical form is also presented in Figure 3. Also, by moving a mouse above any column of the graphical part, the numerical value of the column can be seen. For example, the market value of the eighth alternative was calculated by making 4 iterations (see Figure 3 ).
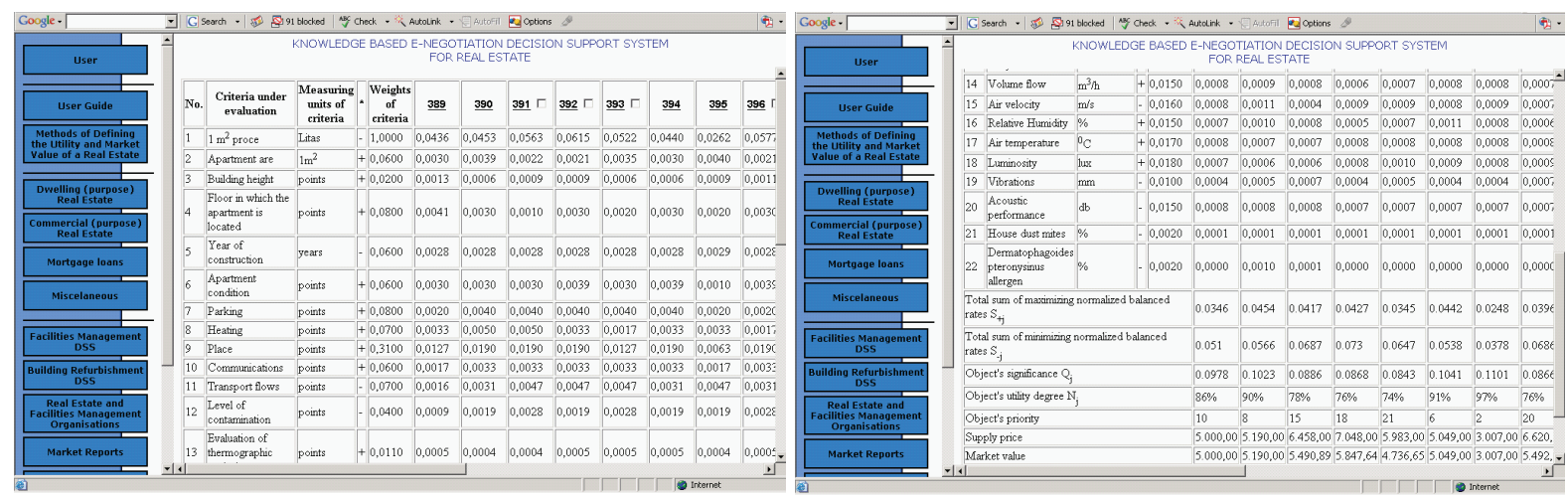

Figure 2. Results of multiple criteria evaluation of 3-room apartment's alternatives: upper part of matrix for obtained results (left); lower part of matrix for obtained results (right)

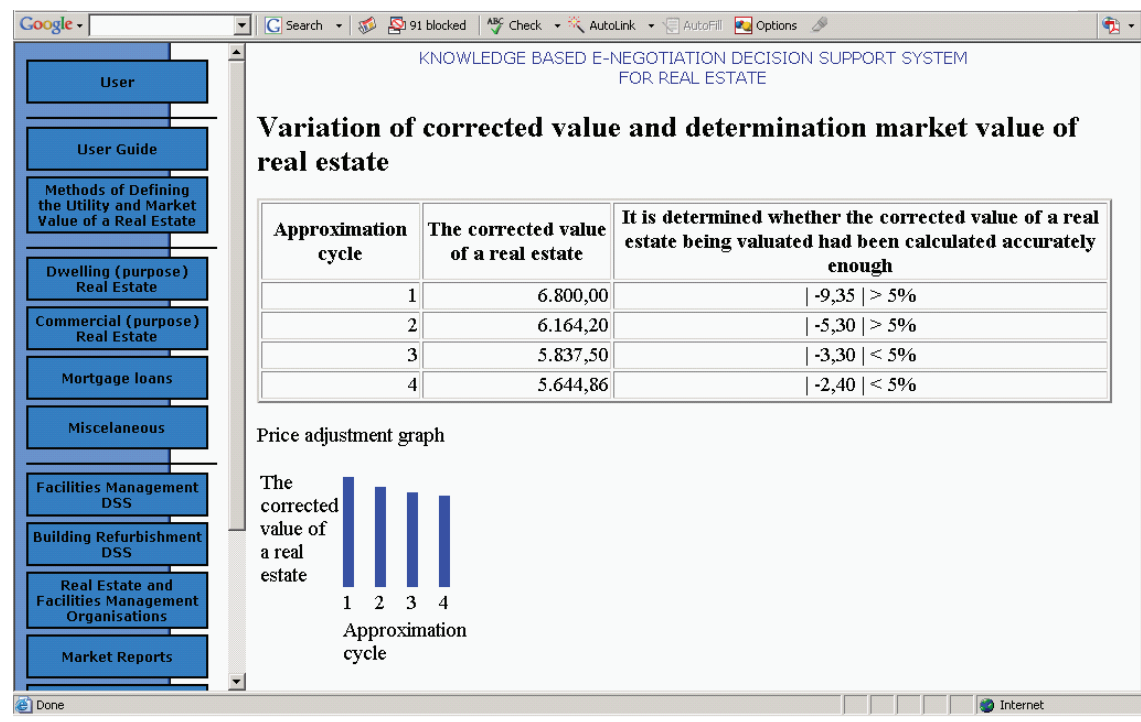

Figure 3. Calculation of market value: presentation of market value's calculations in numerical and graphic forms 
A buyer performing a multi-criteria analysis of all real estate alternatives selects the objects for starting negotiations. For this purpose he/she marks (ticks a box with a mouse) the desirable negotiation objects (see Figure 4 $(l e f t)$ ). E-mail negotiations are created by the Letter Writing Subsystem and sent to all real estate sellers after the selection of the desired objects is made and then Send is clicked.

During negotiations the buyer and the seller with the help of DSS-RE may perform real calculations (utility degree, market value and purchase priorities) of the real estate. These calculations are performed on the basis of characteristics describing the real estate's alternatives that were obtained during negotiations (explicit and tacit criteria system, criteria values and weights). According to the received results, the final comparative table is then developed. Following on from the developed final comparative table, the multiple criteria analysis and selection of the best real estate buying version is carried out by using DSS-RE.

After a variant of the real estate is selected, most often a purchaser has to borrow part of money from a bank. The Loan Analysis Subsystem is created for this purpose (see Figure 4 (right)).

There are five main categories of rules and procedures in the knowledge subsystem (RE-KS):
- Buyer oriented information rules and procedures allow buyers to develop and maintain customer's personalized objectives, preferences, and evaluation criteria for analysing and selecting real estate, brokers, related products and services. Editing services for buyers to create personalized real estate web pages that provide link to directories, annotations and notebooks to analyze related products and services are also integrated.

- Formation of the criteria describing the alternatives. This category consists of rule sets for the formation of the system of criteria that describe the alternatives and provides values and weights of these criteria.

- Development of suggestions with what broker/seller to use and for what reasons further negotiation should be carried out. With the help of a decision support subsystem (RE-DSS) having determined the sequence of priority then the degree of utility and market value of the elements of a renovated building, the rules in knowledge subsystem suggests with what broker/seller to use and for what reasons further negotiation should be carried out.
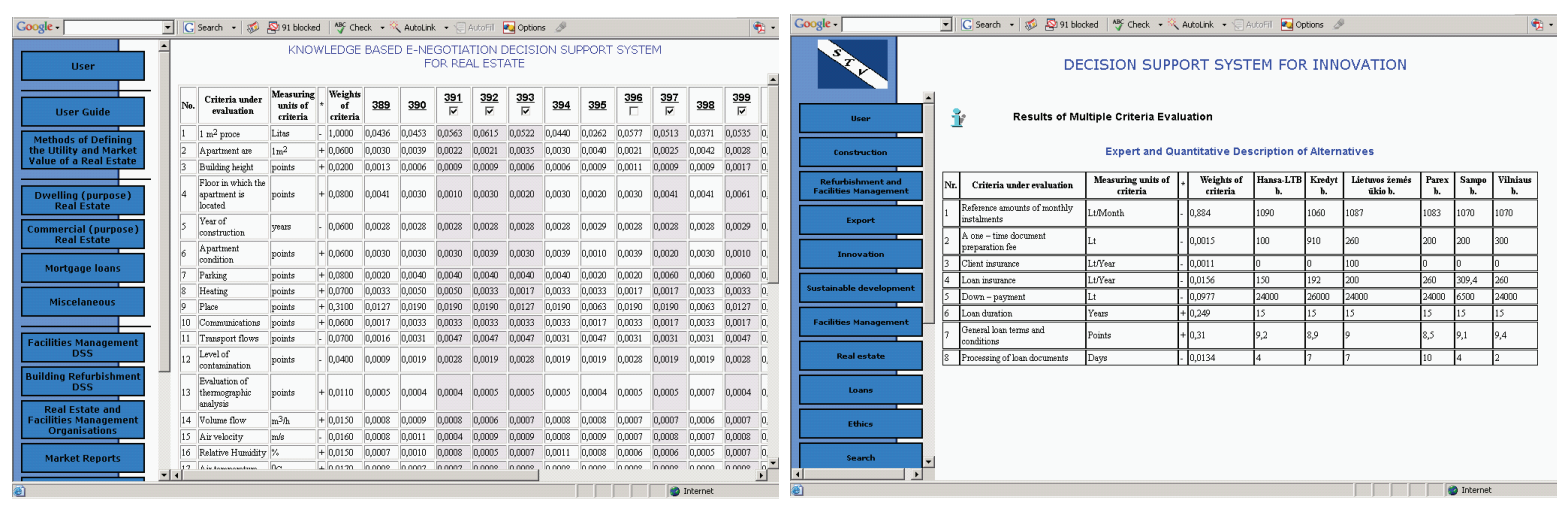

Figure 4. Selection of real estate objects for automated negotiations (left) and analysis of loan alternatives offered by certain banks (right) 
- Composition of a comprehensively reasoned negotiation e-mail for each of the selected broker/seller. By using information inherited from the previous REDSS calculations and predefined rules and procedures, the knowledge subsystem composes of a negotiation e-mail for each of the selected broker/seller, where it reasonably suggests that the price of a real estate should be decreased or a real estate of better quality should be sold for the offered price. The e-mail includes references to the calculations performed by KDDSS-RE.

RE-KS also overwhelm a Market Signalling Subsystem. Links to sites with exhaustive information and analytic reviews about the situation in the Lithuanian real estate market and about its development perspectives is provided. Useful information and knowledge is also presented for different stakeholders in the Market Signalling Subsystem: real estate and facilities management organisations, information about collaterals and loans, insurance (real estate, cars, other property), information on companies offering transportation services (furniture transportation, car transportation, etc.; offered services, vehicles and fees), recreational or residential areas for elderly people (sanatoriums, health centres, nursing homes); purchase or lease of furniture, household appliances, audio/video equipment, other household utilities; leasing companies, comparison of alternatives, various announcements, links to job search websites, facilities management services, information and forecasts on the market situation and its changes, information about activities of real estate companies and associations, information about periodical information bulletins, links to other websites and articles.

Devices in the Device Subsystem measure the indoor microclimate parameters (volume flow, air velocity, air temperature, relative humidity, dew point temperature, vibration impulse amplitudes (see Figure 5)) and allergens causing allergy in the dwelling (house dust mites and dermatophagoides pteronysinus allergen etc.). This data is provided in the Decision Support Subsystem and the Knowledge Subsystem.

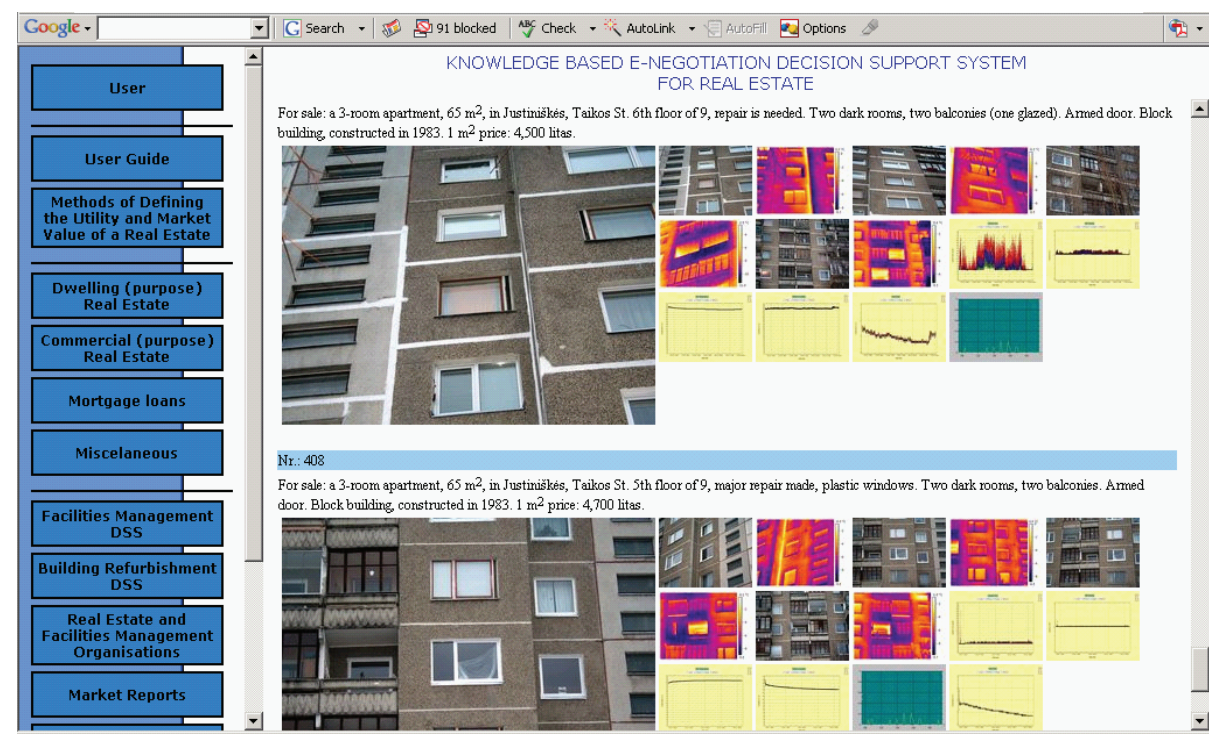

Figure 5. Fragment of diagrams of indoor microclimate parameters and results of thermography measured by devices 
Let us analyse indoor volume flow and relative humidity as an example. Insufficient indoor volume flow velocity causes lack of oxygen in premises. Thus, indoor hygiene conditions become worse, flowers start withering and people feel worse and their productivity decreases. Due to dry air in the premise nasal mucous dries, people feel discomfort; productivity decreases and their moods worsen. Such discomfort may be removed by pipetting oil into the nose. A considerable number of people encounter this problem. Other microclimate parameters may be described similarly.

Percentages of live house dust mites depend greatly on the temperature in premises. When the temperature is $20-25 \mathrm{C}^{\circ}$ the percentage of live mites is $100 \%$ and when temperature is $10-15 \mathrm{C}^{\circ}$ the percentages of live mites is $60 \%$ (see Table 1). Therefore, the fluctuation of temperatures has a great impact on the health of allergic person. A similar situation is found with relative humidity and mite survival (see Table 2).

Table 1. Influence of room temperature to house dust mite dermatophagoides pteronyssinus survival

\begin{tabular}{ll}
\hline Temperature $\left(\mathrm{C}^{\mathrm{o}}\right)$ & Percentages of live mites \\
\hline $20-25$ & 100 \\
$10-15$ & 60 \\
$0-10$ & 25 \\
$-10-0$ & 8 \\
-15 & 0 \\
\hline
\end{tabular}

Table 2. Relative humidity and mite survival

\begin{tabular}{ll}
\hline Relative humidity in \% & Percentages of live mites \\
\hline $75-80$ & 100 \\
$60-70$ & 80 \\
50 & 20 \\
40 & 0 \\
\hline
\end{tabular}

Several types of software have been selected to make the KDDSS-RE effective and they perform various functions. The KDDSS-RE required databases are created and managed by using Microsoft Access. Websites are developed with ASP (Active Server Pages). ASP is used to create dynamic pages that interact (displaying, manipulating and editing databases) with databases. Java Script and ActiveX technologies are used to design and create separate modules and the user interface. Scripts translate HTML source codes and enable one to create interactive web sites. ActiveX is the Microsoft technology, which allows for the creation of standard code libraries and these libraries are easily accessible in any programming environment.

All members of a real estate market can use the created system. Members are recommended to use as much of their knowledge as possible before making decisions. For example, in order to perform the multiple criteria analysis of a real estate, buyers, sellers, brokers, financial institutions, neighbours and other stakeholders' requirements should be estimated and submitted in a quantitative form.

\section{TESTING THE SYSTEM}

In order to test the usefulness of the system, final semester master degree students from the Real Estate Management study programme at Vilnius Gediminas Technical University collected more than 250 listings. These students work as brokers in various real estate companies in Vilnius. They placed information about real estate objects that they were selling at the time into the database. This system were tested by eighteen students for areas that could be improved, e. g. process, interface, navigation, search for alternatives from different brokers' databases, multiple criteria evaluations, calculation of market value and negotiation. A testing of KDDSS-RE was also performed by a designed questionnaire that included four organizations from real estate brokers in Vilnius. The letter that was attached 
to the questionnaire was as follows 'We would like you to draw on your experience and expertise to help us to test whether the KDDSS$\mathrm{RE}$ can also meet your needs as a user. Please read through the following questions circling your response'. A more complete study is underway to study the satisfaction of users and what current real estate agents do in order to survive.

We have some lessons to learn about the system's development. For example, we will further explore and collect the needed knowledge to develop a Model of Consumer Needs Analysis and a Provision of Recommendations for a Real Estate Broker. This model is still under creation for KDDSS-RE. This Model will accumulate information about the popularity of real estate alternatives that are placed into the database. The popularity is determined on the basis of the number of consumers analyzing a certain real estate and on the basis of the time-spent observing it. A seller will offer to reduce or increase the value of the real estate being sold on the basis of such information; other concrete pieces of advice will also be provided.

\section{CONCLUSIONS}

Integration of neural networks, multimedia, knowledge-based, decision support, devices and other systems in the real estate sector has a very promising future in scientific research. Various forms of the integration of these systems were investigated and several architectures of systems were offered. The authors of the present research have suggested the idea to integrate knowledge-based, devices-based and decision support systems. In order to demonstrate the integration decision support, knowledge and devices systems in the real estate sector a Real Estate's Knowledge and Devicesbased Decision Support System have been considered in the paper as an example.

\section{REFERENCES}

ARCHIBUS, Inc. (2009) Products [Online] ARCHIBUS, Inc. Available at: http://www.archibus. com/ [accessed 29 May 2009]

Banaitienè, N., Banaitis, A., Kaklauskas, A. and Zavadskas, E. K. (2008) Evaluating the life cycle of a building: A multivariant and multiple criteria approach, Omega-International Journal of Management Science, 36(3), pp. 429-441. doi:10.1016/j.omega.2005.10.010

Benjamin, J. D., Jud, G. D. and Sirmans, S. G. (2000) What do we know about real estate brokerage? Journal of Real Estate Research, 20(1), pp. 5-30.

BIG (2009) [Online] Bankers Insurance Group (BIG). Available at: http://www.bankersinsurance.com/index_flash.html [accessed 25 May 2009]

Cao, J., Chan, J. Y. K., Li, H., Mahdjoubi, L. and Love, P. E. D. (2001) REALMEDIA: providing multimedia-based real-estate services through the Internet, Automation in Construction, 10(2), pp. 275-289. doi:10.1016/S0926-5805(99)00033-3

Curwell, S., Deakin, M., Cooper, I., PaskalevaShapira, K., Ravetz, J. and Babicki, D. (2005) Citizens' expectations of information cities: implications for urban planning and design, Building Research and Information, 33(1), pp. 55-66. doi:10.1080/0961321042000329422

Drawbase Software (2009) Solutions [Online] Drawbase Software. Available at: http://www.drawbase.com/ [accessed 9 April 2009]

E-Loan, Inc. (2009) [Online] E-Loan, Inc. Available at: http://www.e-loan.com/ [accessed 12 February 2009]

Fang, Y. M., Lin, L. Y., Huang, C. H. and Chou, T. Y. (2009) An integrated information system for real estate agency-based on service-oriented architecture, Expert Systems with Applications, 36(8), pp. 11039-11044. doi:10.1016/j.eswa.2009.02.082

FM:Systems (2009) FM:Interact Workplace Management Suite [Online] FM:Systems. Available at: http://www.fmsystems.com [accessed 12 March 2009]

Forbes, B. K. (2000a) Facilities management automation and infrastructure management. Article 3.3.4. In: Smith, P. R. (editor-in-chief). 
Facilities Engineering and Management Handbook: Commercial, Industrial, and Institutional Buildings, New York: McGraw-Hill Professional Publishing, pp. 192-229.

Forbes, B. K. (2000b) Facilities management automation and infrastructure management audits. Article 3.3.5. In: Smith, P. R. (editor-in-chief) Facilities Engineering and Management Handbook: Commercial, Industrial, and Institutional Buildings, New York: McGraw-Hill Professional Publishing, pp. 229-241.

Forbes, B. K. (2000c) The role of e-commerce and business-to-business electronic marketplaces in facilities management. Article 3.3.7. In: Smith, P. R. (editor-in-chief) Facilities Engineering and Management Handbook: Commercial, Industrial, and Institutional Buildings, New York: McGraw-Hill Professional Publishing, pp. 244-262.

Ford, J. S., Rutherford, R. C. and Yavas, A. (2005) The effects of the internet on marketing residential real estate, Journal of Housing Economics, 14(2), pp. 92-108. doi:10.1016/j.jhe.2005.06.003

Guo, H., Li, H., Shen, Q., Wang, Y. and Li, Y. (2007) Real estate confidence index based on Web GIS and SPSS WebAPP, International Journal of Project Management, 25(2), pp. 171-177. doi:10.1016/j.ijproman.2006.09.015

Guttery, R. S., Baen, J. S. and Benjamin, J. (2000) Alamo Realty: the effects of technology changes on real estate brokerage, Journal of Real Estate Practice and Education, 3(1), pp. 71-84.

Ham, S. and Atkinson, R. D. (2003) Modernizing home buying: how IT can empower individuals, slash costs, and transform the real estate industry [Online] Progressive Policy Institute. Available at: http://www.ppionline.org/ documents/Real_Estate_0303.pdf [accessed 18 March 2009]

INTELCITIES (2005) Intelligent Cities (INTELCITIES), Information Society Technologies, Sixth Framework Programme, European Union. Project reference: 507860.

Jakaitis, J., Paliulis, N. and Jakaitis, K. (2009) Aspects of the national urban policy management under conditions of integrated planning, Technological and Economic Development of Economy, 15(1), pp. 26-38. doi:10.3846/1392-8619.2009.15.26-38
Jauneikaitè, K. and Carreno, M. (2009) Importance of virtual trips for transport infrastructure planning, The Baltic Journal of Road and Bridge Engineering, 4(2), pp. 61-68. doi:10.3846/1822-427X.2009.4.61-68

mortgage.com (2009) [Online] Citigroup Inc. Available at: http://www.mortgage.com/ [accessed 3 June 2009]

Muhanna, W. A. (2000) E-commerce in the real estate brokerage industry, Journal of Real Estate Practice and Education, 3(1), pp. 1-16.

Kaklauskas, A. and Urbanavičienè, V. (2005) Intelektualus miestas ir internetinè nekilnojamojo turto daugiakriterinè derybinè sprendimų paramos sistema [Intellcity and web-based multi criteria negotiation decision support system], Technological and Economic Development of Economy, 11(3), pp. 183-189. (In Lithuanian)

Kaklauskas, A., Zavadskas, E. K. and Raslanas, S. (2005) Multivariant design and multiple criteria analysis of building refurbishments, Energy and Buildings, 37(4), pp. 361-372. doi:10.1016/j.enbuild.2004.07.005

Kaklauskas, A., Zavadskas, E. K. and Trinkunas, V. (2007) A multiple criteria decision support on-line system for construction, Engineering Applications of Artificial Intelligence, 20(2), pp. $163-175$.

doi:10.1016/j.engappai.2006.06.009

Kaklauskas, A., Zavadskas, E. K., Naimavicienè, J., Krutinis, M., Plakys, V. and Venskus, D. (2010) Model for a complex analysis of intelligent built environment, Automation in Construction, 19(3), pp. 326-340.

doi:10.1016/j.autcon.2009.12.006

Ko, C. H. (2009) RFID-based building maintenance system, Automation in Construction, 18(3), pp. $275-284$. doi:10.1016/j.autcon.2008.09.001

Onishi, A. (2002) FUGI global modeling system (FGMS200): integrated global model for sustainable development, Journal of Policy Modeling, 24(6), pp. 561-590. doi:10.1016/S0161-8938(02)00127-8

RealData, Inc. (2009) Commercial / Industrial Development [Online] RealData, Inc. Available at: http://www.realdata.com/index.html [accessed 6 January 2009]

Simão, A., Densham, P. J. and Haklay, M. (2009) Web-based GIS for collaborative planning and public participation: an application to the strategic planning of wind farm sites, Journal of 
Environmental Management, 90(6), pp. 20272040. doi:10.1016/j.jenvman.2007.08.032

Stankevičius, Ž., Beconytè, G. and Kalantaitè, A. (2010) Automation of update of digital national geo-reference databases, Technological and Economic Development of Economy, 16(2), pp. 254-265. doi:10.3846/tede.2010.16

Šliogerienè, J., Kaklauskas, A., Zavadskas, E. K., Bivainis, J. and Seniut, M. (2009) Environment factors of energy companies and their effect on value: analysis model and applied method, Technological and Economic Development of Economy, 15(3), pp. 490-521. doi:10.3846/1392-8619.2009.15.490-521

Teicholz, E. (2000) The internet, e-commerce, and facilities management. Article 3.3.6. In: Smith, P. R. (editor-in-chief) Facilities Engineering and Management Handbook: Commercial, Industrial, and Institutional Buildings, New York: McGraw-Hill Professional Publishing, pp. 241-243.

Urbanavičienè, V., Kaklauskas, A. and Zavadskas, E. K. (2009a) The conceptual model of construction and real estate negotiation, International Journal of Strategic Property Management, 13(1), pp. 53-70. doi:10.3846/1648-715X.2009.13.53-70

Urbanavičienè, V., Kaklauskas, A., Zavadskas, E. K. and Seniut, M. (2009b) The web-based real estate multiple criteria negotiation decision support system: a new generation of decision support systems, International Journal of Strategic Property Management, 13(3), pp. 267-286. doi:10.3846/1648-715X.2009.13.267-286
Vitkauskaite, E. and Gatautis, R. (2008) E-Procurement perspectives in construction sector SMEs, Journal of Civil Engineering and Management, 14(4), pp. 287-294. doi:10.3846/1392-3730.2008.14.28

Wang, W. K. (2005) A knowledge-based decision support system for measuring the performance of government real estate investment, Expert Systems with Applications, 29(4), pp. 901-912. doi:10.1016/j.eswa.2005.06.017

Zavadskas, E. K., Kaklauskas, A., Banaitis, A. and Kvederyte, N. (2004) Housing credit access model: the case for Lithuania, European Journal of Operation Research, 155(2), pp. 335-352. doi:10.1016/S0377-2217(03)00091-2

Zavadskas, E. K., Kaklauskas, A., Maciunas, E., Vainiunas, P. and Marsalka, A. (2007a) Real estate's market value and a pollution and health effect analysis decision support system, Lecture Notes in Computer Science, (4674), pp. 191200. doi:10.1007/978-3-540-74780-2_23

Zavadskas, E. K., Kaklauskas, A. and Kaklauskiene, J. (2007b) Modelling and forecasting of a rational and sustainable development of Vilnius: emphasis on pollution, International Journal of Environment and Pollution, 30(3/4), pp. 485-500. doi:10.1504/IJEP.2007.014824

Zumpano, L. V., Johnson, K. H. and Anderson, R. I. (2003) Internet use and real estate brokerage market intermediation, Journal of Housing Economics, 12(2), pp. 134-150. doi:10.1016/S1051-1377(03)00018-4 


\section{SANTRAUKA}

\section{ŽINIOMIS IR PRIETAISAIS PAGRISTA NEKILNOJAMOJO TURTO SPRENDIMŲ PARAMOS SISTEMA}

\section{Edmundas Kazimieras ZAVADSKAS, Artūras KAKLAUSKAS, Audrius BANAITIS}

Šio darbo autoriai dalyvavo šeštosios bendrosios programos projekte „Intelektualūs miestai“ (INTELCITIES). Vienas iš INTELCITIES tikslu (Lietuvoje) - sukurti žiniomis ir prietaisais pagrịstą nekilnojamojo turto sprendimu paramos sistemą (KDDSS-RE). Pagrindinès KDDSS-RE funkcijos yra šios: sukurti ir plètoti klientui asmeniškai pritaikytus nekilnojamojo turto tikslus, pageidavimus ir vertinimo kriterijus; ivvairioms suinteresuotosioms grupėms (pirkejjams, pardavejjams, tarpininkams ir pan.) suteikti galimybę drauge nustatyti nekilnojamaji turtą apibūdinančius kriterijus (kriterijų sistema, vertes ir reikšmingumus); rinkos tyrimas, iš prietaisu gautų duomenų apie patalpu mikroklimatą ir pastatuose esančius alergenus pateikimas; alternatyvių nekilnojamojo turto variantų paieška, jų radimas ir pradinės derybų lentelès sudarymas, alternatyvų daugiakriterinè analizè, realiais skaičiavimais pagristos elektroninès derybos, racionaliausio nekilnojamojo turto varianto pirkimui nustatymas ir tam tikrų bankų siūlomų alternatyvių paskolų variantų analizè. Šio tyrimo autoriai pasiūlè idejją integruoti žiniomis ir prietaisais pagristas bei sprendimų paramos sistemas. Siekiant sprendimu paramos, žinių ir prietaisų sistemu integravimą pademonstruoti nekilnojamojo turto sektoriuje, darbe nagrinėjama žiniomis ir prietaisais pagrista nekilnojamojo turto sprendimų paramos sistema. 